\section{The cardioprotective role of trimetazidine on cisplatin-induced cardiotoxicity}

To the Editor,

We have read the article by Zhao (1) entitled "Protective effects of trimetazidine and coenzyme 010 on cisplatin-induced cardiotoxicity by alleviating oxidative stress and mitochondrial dysfunction" with great interest. The authors reported that trimetazidine and coenzyme 010 showed protective effects against cispaltininduced cardiotoxicity by reducing oxidative stress. First, we wish to ask the authors how they have rationalized the concentrations of trimetazidine $(200 \mu \mathrm{M})$ and coenzyme $010(200 \mathrm{mg} / \mathrm{L})$ they used in the ventricular myocytes? We would like to emphasize some important points about this well-written study.

Intracellular calcium plays a key role in cellular homeostasis. One of the most important mechanisms underlying chemotherapyinduced cardiotoxicity is increased calcium $\left(\mathrm{Ca}^{2+}\right)$ levels in cardiomyocytes. Increased $\mathrm{Ca}^{2+}$ levels stimulate reactive oxygen species and there is a bidirectional interaction between these parameters (2). It has been reported that trimetazidine shows cardioprotective effects by decreasing the intracellular calcium accumulation by controlling the membrane ion gradients (3). It has been shown that caspase 3 and caspase 9 activites play an important role in mitochondrial apoptotic pathways (4). Lui et al. (5) showed that trimetazidine pretreatment could attenuate myocardial apoptosis and improve cardiac function by decreasing apoptotic rate and the expression levels of cleaved caspase 3 and 9 .

Therefore, we think that measuring the aforementioned parameters, such as intracellular calcium levels and caspase 3 and caspase 9 activity, could provide insights into the cardioprotective role of trimetazidine in chemotherapy-induced cardiotoxicity.

\section{(D) Murathan Küçük, (D) Can Ramazan Öncel ${ }^{1}$ \\ Department of Cardiology, Faculty of Medicine, Akdeniz University; Antalya-Turkey 'Department of Cardiology, Faculty of Medicine, Alanya Aladdin Keykubat University; Antalya-Turkey}

\section{References}

1. Zhao L. Protective effects of trimetazidine and coenzyme 010 on cisplatin-induced cardiotoxicity by alleviating oxidative stress and mitochondrial dysfunction. Anatol J Cardiol 2019; 22: 232-9. [CrossRef]

2. Oncel CR, Ovey IS. The role of selenium in bevacizumab induced cardiotoxicity. Bratisl Lek Listy 2019; 120: 131-8. [CrossRef]

3. Belardinelli R. Trimetazidine and the contractile response of dysfunctional myocardium in ischaemic cardiomyopathy. Rev Port Cardiol 2000; 19 Suppl 5: V35-9.

4. Shi Y. Apoptosome: the cellular engine for the activation of caspase-9. Structure 2002; 10: 285-8. [CrossRef]

5. Liu YC, Li L, Su 0, Liu T, Tang ZL. Trimetazidine pretreatment inhibits myocardial apoptosis and improves cardiac function in a
Swine model of coronary microembolization. Cardiology 2015; 130: 130-6. [CrossRef]

Address for Correspondence: Dr. Can Ramazan Öncel, Alanya Aladdin Keykubat Üniversitesi Tıp Fakültesi,

Kardiyoloji Anabilim Dalı,

Antalya-Türkiye

Phone: +90 5063715199

E-mail: r_oncel@hotmail.com - can.oncel@alanya.edu.tr

CCopyright 2020 by Turkish Society of Cardiology - Available online

at www.anatoljcardiol.com

DOI:10.14744/AnatolJCardiol.2020.54058

\section{Author's Reply}

To the Editor,

I appreciate his interest in my study (1). He has pointed out about the rationalization of the concentrations of trimetazidine $(200 \mu \mathrm{M})$ and coenzyme $010(200 \mathrm{mg} / \mathrm{L})$ used in the ventricular myocytes. I performed the preliminary experiments to analyze the responses of rat cardiomyocytes to serial doses of TMZ (12.5-200 $\mu \mathrm{M}$ ) or Co010 (12.5-200 mg/L). TMZ or CoO10 attenuated cisplatininduced cell toxicity in a dose-dependent manner using a CCK8 assay. However, statistical significance was only observed at a concentration of $200 \mu \mathrm{M}$ TMZ or $200 \mathrm{mg} / \mathrm{L} \mathrm{CoQ10}$. Therefore, I chose to use $200 \mu \mathrm{M}$ TMZ and $200 \mathrm{mg} / \mathrm{L}$ CoO10 for subsequent experiments.

He has recommended measuring parameters, such as intracellular calcium levels and caspase 3 and caspase 9 activities. These parameters could be useful to investigate the mechanisms of the cardioprotective role of trimetazidine in chemotherapy-induced cardiotoxicity; however, my study focused on the upstream of caspase activities as described in the paper's introduction. ROS-mitochondrial dysfunction-Nrf2/CytoC-apoptosis was the major framework of my study. On the other hand, caspase-dependent apoptosis has been briefly dealt with in the paper's introduction and discussion.

\section{(D) Li Zhao \\ Department of Cardiology, Obstetrics and Gynecology Hospital of Fudan University; Shanghai-China}

\section{Reference}

1. Zhao L. Protective effects of trimetazidine and coenzyme 010 on cisplatin-induced cardiotoxicity by alleviating oxidative stress and mitochondrial dysfunction. Anatol J Cardiol 2019; 22: 232-9.

Address for Correspondence: Li Zhao, MD,

Department of Cardiology,

Obstetrics and Gynecology Hospital of Fudan University;

No. 419, Fangxie Road,

Huangpu District Shanghai-China

Phone: 86-21-33189900

E-mail: zhaoli20181212@163.com

(C) Copyright 2020 by Turkish Society of Cardiology - Available online

at www.anatoljcardiol.com 